\title{
Community Empowerment in Maintaining Public Domain Mark as the Community's Right for Trademark
}

\author{
${ }^{1}$ Arthur Novy Tuwaidan* \\ Law Studies Program \\ Faculty of Social Science \\ Universitas Negeri Manado \\ Tondano, Indonesia \\ arthurtuwaidan@unima.ac.id
}

\author{
${ }^{2}$ Merry Kumajas \\ Law Studies Program \\ Faculty of Social Science \\ Universitas Negeri Manado \\ Tondano, Indonesia \\ Merry.kumajas@unima.ac.id
}

\begin{abstract}
This study examines community empowerment in maintaining public domain marking as a community's right for trademark. This is legal research by using methods according to scientific characteristics of the Law (jurisprudence), namely normative legal research. The public is given authority to use a public domain. The same as the Geographical Indication Protection Society, a public domain protection community is needed on the brand and included in the trademark law. The public is given the authority to use the public domain mark and entitled lawsuit against the use of public domain by unauthorized individuals.
\end{abstract}

Keywords: Community Empowerment, Public Domain, Trademark

\section{INTRODUCTION}

Intellectual Property Rights (IPR) is an important part of trade agreements in regional and international scope. The International Agreement on trade aspects of IPR (The TRIPS Agreement), does not provide a definition of IPR. But Article 1.2 states that IPRs consist of Copyright and Related Rights, trademarks, geographical indications, industrial designs, patents, integrated circuit layout, trade secrets, and control of unfair business competition practices in license agreements. IPR[1], in general, is related to the protection of the application of ideas and information which have commercial value. IPR is personal wealth that can be owned and treated the same as other forms of wealth.

Trademark according to general provisions of Law No. 20/2016 related to Trademarks and Geographical Indications, in Article 1 Paragraph (1) stated: "A mark is a sign which displayed graphically in the form of an image, logo, name, word, letter, number, color arrangement, in the form of 2 (two) dimensions and / or 3 (three) dimensions, sound, hologram, or a combination of 2 ( two) or more of these elements to distinguish goods and / or services produced by a person or legal entities in the trading of goods and / or services ".

Trademarks as intellectual property rights are basically a sign to identify the origin of goods and services (an indication of origin)[2] of a company with the goods and / or services of other companies. The brand is the spearhead of the trade in goods and services. Through brands, entrepreneurs able to maintain and guarantee the quality (a guarantee of quality) of goods and or services produced and prevent unfair competition (concurrency) from other entrepreneurs with bad intentions who intend to piggyback their reputation. Brands as a marketing and advertising device (a marketing and advertising device) provide a certain level of information to consumers about goods and / or services produced by entrepreneurs.

Trademarks are legalized monopolies,[3] but there are often signs that should not be monopolized, for example, those related to the public domain. Lots of abuse of words and / or signs that are commonly known to the public and have become public domain. The mark should not be an individual right and it should not be for an individual monopoly. It is very important to determine the meaning and scope of the Public Domain, by classifying what is not protected by Intellectual Property Rights, especially Trademark Law. Tyler T. Ochoa stated "The Public Domain is something that we enjoy every day without thinking about it, where the Public Domain or public domain is something we can enjoy or use at any time. Public Domain brands play an important role to improve the welfare of the community and are not individual rights.

This is in line with the opinion of Martin Senftleben who argues that:[4] "legal status definition, typically, requires public domain material to be unencumbered by intellectual property rights. They focus on the material that is ineligibly underlying for protection, or that no longer enjoys protection after the expiry the protection". Society as a social system is a place for its members to fulfill their living needs. Society either, one human being is related to another human being, the process of interaction takes place without stopping. The relationship occurs between them in order to meet their needs to run orderly because the order is one of the main needs in human life. "Pemberdayaan" means of empowerment, "memberdayakan" means empowering. Empower contains two meanings: to give power or authority, transfer power or delegate the authority of other parties: to give ability or enable or efforts to give ability or empowerment. Empowerment is defined as the ability of 
the power party to the less or those who have not been empowered.[5]

Furthermore, if there is a violation of the Public Domain which will be registered or has been registered as a trademark, who is the party concerned in violation of the Public Domain that will be registered as a trademark or when the Public Domain has become a trademark? The party which able to submit the cancellation of a mark is the party who has Legal Persona Standi in Judicio[2]. Based on the background description, the researcher will examine how Community Empowerment Defends the Public Domain Mark as the Community's Right for Trademarks.

\section{RESEARCH METHODS}

This is law research (legal research) by using a method according to scientific characteristics of jurisprudence, known as normative legal research. As normative legal research, the method used is a legal research method aimed to find how Community Empowerment in Maintaining a Public Domain Mark as a Community Right on the Trademark, the results to be achieved then provide a prescription about the issue to be raised. [6] The purpose of this research is to study and discover how Community Empowerment Defends Public Domain Signs as Community Rights in Brands. This research is a normative study, the data obtained are secondary data consisting of primary legal materials; legislation, treaties are also other secondary materials such as draft laws, dictionaries (laws) and other writings.

\section{RESULT AND DISCUSSION}

Personal rights are human rights in relation to the person himself. These rights are in the form of the right to life, the right to not be harmed physically, the right to use a first name and surname, and the right to be listed as the owner of his work in the fields of literature, art, brand, and science. These personal rights include: [7]

\section{Family rights.}

The rights to kinship are the rights relating to family relations, which is the most important right now is parental power, guardianship, and ability. Family rights do not have a monetary value that they cannot be traded.

\section{Material rights}

Material rights are included in the number of rights to assets. These rights are valued with money and the characteristics of these rights can be transferred. These include property rights, the right to enjoy inheritance, rental rights, and building rights. These material rights give the holder power over the object under his control. The right gives perfect authority to the holder is ownership rights.

3. Rights to intangible goods.

This right is a right of ideas and human intellectuals in the form of copyrights, patents, trademark rights, industrial designs, secrets trade, and integrated circuit layout designs.

'Rights' certainly cannot be separated in the relationship between humans and community life which is a survival mode for humans, means 'rights' are something inherently attached to humans and the existence of 'rights' which need to maintain the existence of 'rights' in the pattern of life sociable. The existence of 'rights' cannot be denied, it cannot be separated from the nature of humanity itself which is God's creation. It is a package in the creation of human beings as creatures have physical and existential aspects. However, there is an expression by Gauis, an ancient Roman jurist, it is male enim Nostro iure uti non demimus, which means we cannot use our rights for bad purposes. It means the use of a right in the sense of authority solely for the purpose of harming others is unacceptable.

The terminology of "rights" has been widely revealed in much of the literature as derived from natural law. Rights are consequences that arise in the application of the law and each type of law determines the rights contained therein.[8] The right always gives a certain authority to the subject which is then known as the authority that arises from the rule of law or positive law. According to Mertokusumo, [9]"rights" are given understanding as interests protected by law, while interests are the demands of individuals or groups that are expected to be fulfilled. Interests essence contains powers which are guaranteed and protected by law in their nature.

There are two theories about the nature of rights as expressed by Lord Loyd of Hamstead and M.D.A Freeman quoted by Peter Mahmud, [7]called the theory of will and expediency. Will the theory held by people who hold the purpose of the law is to give individuals as much freedom as they want According to the adherents of the will theory, right holders can do anything about their rights, including using, releasing, conducting or not doing anything about the rights they have Benefit theory is based on the purpose of law intended to protect a particular and not the will of an individual, so rights are defined as interests protected by law. These interests were not created, but they already existed in the community and the country only had to determine which interests were protected. According to Paton as followed by Peter Mahmud interests are demands or desires of individuals or groups of individuals who want to be fulfilled by individuals or groups of individuals.[10]

The definition of rights or rights in the Black's Law Dictionary is: "As a noun, and taken in an abstract sense, means of justice, ethical correctness, or consonance with the rules of law or the principles of morals". Furthermore, it was stated relate to wealth is given the meaning of "An interest or title in an object of property, a just and legal claim to hold, use, or enjoy it or to convey or donate it".[11]

Black's provides a differentiation into several rights as follow:

a. Right as perfect or imperfect,

b. Right is personal or in brake,

c. Right primary or secondary,

d. Preventive or protective.[11]

Rights are given a distinction according to the clarity of application or scope, if the scope is clear and certain, 
then it is categorized as perfect right, whereas if the scope is unclear and not certain it is said to be imperfect right. This is in accordance with his explanation, rights may be described as perfect, according to their action or scope is clear, settled, and determinate, or is vague and unfixed. Rights are said to be Right in personal if the obligation is placed on a particular person, while a right in rem if the obligation is placed not only on certain people but on people in general.

Social aspects or social dimensions that limit property rights are often expressed in terms of social functions. The limitation of an individual's authority over his object is intended for protection or for the benefit of the community. In relation to property rights, the word social function is also interpreted as a social element that provides limits for individuals to control the object of their rights, as stated by John Henry Merryman as follows: "According to one view, fundamental private law concepts have consequently been modified by the addition of social or public elements; such terms as the "socialization" or "publication" of private law are frequently encountered in the literature. The modern constitution, starting with the Weimar Constitution of 1919, explicitly limit private rights in the public interest, producing what civil lawyers commonly refer to as the "social function" of property or other private rights."

Furthermore, the social aspects of personal rights as property rights constraints are also stated as follows: "Ownership rights, usufruct rights, lease rights, usufructuary rights (which are in the permanent or nonpermanent property), usufructuary rights, usufructuary rights, land clearing rights, and collecting and collecting forest products (specifically in the field of diagramming) and so on, as we all know that all of them have social functions, means their use is not only intended for the interests of their holders, it must not interfere with the public (social) interests or in other words, the use of the rights mentioned above by the holders must not be misused. "

The existence of social functions in property rights indicates the existence of social aspects that limit the rights of individuals in controlling objects that are owned. In other words, the use of the word social function in relation to ownership is related to the index of the area of ownership, it shows how far the authority of the individual owner of something rights. Society as a social system is a place for its members to fulfill their living needs. In that society too, one human being is related to another human being, the process of interaction takes place without stopping. The relationship that occurs between them in order to meet their needs can run orderly and orderly because the order is one of the main needs in human life in society.

Ardle, as quoted by Harry,[12] wisdom of empowerment, is defined as a decision-making process by those who consequently conduct the decision. [13] Marc A. Zimmerman argues that: "Empowerment may be seen as a process where individuals learn to see a closer correspondence between their goals and achievement of how to achieve them, and the relationship between their efforts and life outcomes". Empowerment can be seen as a process in which individuals learn to see a closer correspondence between their goals and how to achieve them, and the relationship between their efforts and life outcomes. Next is another definition according to Zimmerman: "Empowerment is an intentional, ongoing process centered in the local community, involving mutual respect, critical reflection, caring, and group participation, through which people lacking an equal share of valued resources gain greater access to and control over the resources." Zimmerman explained that empowerment is a deliberate and sustainable process that is placed in the local community, which involves mutual respect, critical reflection, caring, and group participation, in which people who are lacking and equal parts of the valued resources get valued access greater control over resources.

Empowerment is a process that runs continuously to improve the ability and independence of the community in improving their standard of living, the effort can only be done by awakening their empowerment, to improve life on their own strength. The basic assumption used is every human being has the potential and power to develop himself for the better.

Thus basically, humans are active in efforts to increase their empowerment. This empowerment involves the construction of basic facilities and infrastructure, both physical and non-physical[14]. Empowerment is an activity that is sustainable, dynamic, synergistically encourages the involvement of all the potential communities that exist in a participatory manner. In this way, it will be possible to form a pluralistic civil society, full of continuity of obligations and rights, mutual respect without any strangers in the community.[15]

Furthermore, empowerment in the context of society is the ability of individuals who are united with the community and build the empowerment of the community concerned. The community which is physically and mentally healthy, educated and strongly innovative, certainly has high empowerment. Community empowerment is the elements that enable the community to survive and in a dynamic sense develop themselves and achieve progress. This community empowerment becomes the number of what in national-level political insight is called national resilience.[16]

Sunyota Usman argues that community empowerment is a process within the framework of efforts to strengthen what is commonly called community self-reliance or independence[17]. In this process, the community is assisted to make an analysis of the problem at hand, assisted to find a solution to the problem, and be shown strategies to utilize various capabilities. Furthermore, it was also stated that the empowerment of an effort to provide power (empowerment) or strengthening to the community. In other words, community empowerment is defined as the ability of individuals who are united with the community to build the empowerment of the community concerned.[18] 
Priyono and Pranarka argued that the empowerment process contains two tendencies, as follows: First, the empowerment process with a primary tendency emphasizes the process of giving power, strength or ability to the community so that the individual concerned becomes more empowered. This process can be complemented by efforts to build material assets to support the development of their independence through the organization. Second, the empowerment process with a secondary tendency emphasizes the process of stimulating, encouraging or motivating individuals to have the ability or empowerment to determine what their life choices are through the process of dialogue.[19]

Regarding empowerment, there are three powers can strengthen community capacity, the power is:

1. Power is the ability to act, a series of ideas from the ability.

2. Power is a joint action, the ability to act together. Basically mutual support, solidarity, and cooperation. Power can help build bridges by drawing distance differences to change or reduce social conflict and consider the equity of relations.

3. The power within (strength within) is the dignity or dignity of an individual or together. This power is to imagine and create hope in the form of intention, willingness, patience, enthusiasm, and awareness.

Empowering society is enabling and independence of the community.

Within this framework, community empowerment efforts can be pursued in 3 (three) ways, as follows:

1. Enabling, which is to create an atmosphere or climate that allows the potential for developing society. The starting point is the recognition for every human being, every society has potential and can be developed. Empowerment is an effort to build that power by encouraging (encouraging), motivating and raising awareness (awareness) of its potential and strive to develop it.

2. Empowering, which is to increase capacity by strengthening the potential or power possessed by the community. This strengthening includes concrete steps such as providing various inputs (input) as well as opening access to various opportunities which can make the community more empowered.

3. Protecting the interests by developing a protection system for the people who are the subject of development. In the process of empowerment, it must be prevented the weak from becoming weaker, because of the lack of empowerment to face the strong. Protecting, in this case, is seen as an effort to prevent unbalanced competition and strong exploitation of the weak.

The empowerment process should emphasize the process of giving or transferring some strength, power or ability to the community to be more empowered and encourage or motivate individuals so that they have the ability or empowerment to determine what their life choices are through the process of dialogue. Empowerment is the power to gain access to available resources it is a fair distribution of power that can increase community awareness of its existence.
Talking about the Public Domain is, of course, related to society at large. Public Domain (public property) which means the object is not in the possession of an individual, so it can be used by anyone and can be exploited and used commercially by the community freely without requiring permission from anyone. The public domain brand has expired and is not extended anymore, and there is no longer any owner (individual) free to exploit and commercialize for their own benefit.[20]

If there is a violation of the Public Domain which will be registered or has been registered as a trademark, who is the party concerned in violation of the Public Domain that will be registered as a trademark or when the Public Domain has become a trademark? The party can submit the cancellation of the mark is the party who has Legal Persona Standi in Judicio.[2]

In Trademark according to general provisions of Law No. 20/2016, in Article 76, is:

1) A claim for cancellation of a Mark may be filed by an interested party based on the reasons referred to in Article 20 and / or Article 21.

(2) An unregistered trademark owner can file a claim as referred to in paragraph (1) after submitting an application to the Minister.

(3) A claim for cancellation is filed with the Commercial Court against the registered trademark owner.

Article 77:

(1) A claim for cancellation of a Mark registration may only be filed within a period of 5 (five) years from the date of the Mark registration.

(2) A claim for cancellation can be filed indefinitely if there is an element of bad faith and/or the mark concerned is against the state ideology, statutory regulations, morality, religion, decency, and public interest.

Article 78:

(1) With regard to the decision of the Commercial Court on the claim for cancellation as referred to in article 76 paragraph (3), an appeal can be filed.

(2) The Registrar of the Court immediately submits the decision to the parties to the dispute.

Article 79:

Provisions regarding reasons for cancellation as referred to in article 76 shall apply mutatis mutandis to registered Collective Marks. Being able to make a claim for the explanation of Article 76 paragraph (1) where the parties to the cancellation, called "What is meant by" interested parties "include registered trademark owners, prosecutors, foundations/institutions in the consumer sector, and religious assemblies/institutions. In this explanation, the parties who are interested in carrying out the cancellation claim against the brand must have legal standing.

In the community empowerment theory outlined above, the community is given the authority to use the public domain. As with the Geographical Indication Protection Society, a public domain protection community is needed on the brand and included in the trademark law. The public is given the authority to use 
the public domain mark and is entitled to also file a lawsuit against the use of public domain by unauthorized individuals.

\section{CONCLUSION}

Based on the description of the writing of this study regarding Community Empowerment in Maintaining a Public Domain Mark as a Community Right on the Brand, it can be concluded that the public is given the authority to use the public domain. As with the Geographical Indication Protection Society, a public domain protection community is needed on the brand and included in the trademark law. The public is given the authority to use the public domain mark and is entitled to also file a lawsuit against the use of public domain by unauthorized individuals.

\section{ACKNOWLEDGMENT}

Thank you for Dean Faculty of Social Sciences for supporting this research.

\section{REFERENCES}

[1] Lindsey dan Tim, Hak Kekayaan Intelektual Suatu Pengantar. Bandung: Alumni, 2011.

[2] Rahmi Jened, Hukum merek, Trademark Law, Dalam Era Global dan Integrasi Ekonomi. Jakarta: Prenada Media Grup, 2015.

[3] R. Janed, Interface Hukum Kekayaan Intelektual dan Hukum Persaingan. Jakarta: Raja Grafindo Rajawali Press, 2013.

[4] Senftleben Martin, Trademark Law and The Public Domain. Edward Elgar Publishing, 2013.

[5] A. Teguh, Kemitraan dan Model Pemberdayaan. Yogyakarta: Gava Media, 2004.

[6] P. M. Marzuki, Penelitian Hukum. Jakarta: Kencana, 2008

[7] P. M. Marzuki, Pengantar Ilmu Hukum. Jakarta: Prenada Media Grup, 2009.

[8] E. Sumaryono, Etika Hukum Relevansi Teori Hukum Kodrat Thomas Aquinas. Yogyakarta, 2002.

[9] S. Mertokusumo, Mengenal Hukum. Yogyakarta: Liberty, 2005.

[10] Peter Mahmud Marzuki, "Penelitian Hukum”, Jakarta: Kencana,.

[11] B. A. Garner, "Black's Law Dictionary, , ," Thomson Reuters, 2014.

[12] H. Hikmat, Strategi Pemberdayaan Masyarakat. Bandung: Humaniora Utama Press, 2004.

[13] M. Zimmerman, Empowerment Theory. New York: Plenum Publishers, 2000.

[14] S. E. Hasan, Strategi menciptakan Manusia Yang Bersumberdaya Unggul. Bandung: Pustaka Rosda karya, 2002.

[15] K. Suhendra, Peran Birokrasi Dalam Pemberdayaan Masyarakat. Bandung: alfabeta, 2006.
[16] R. R. Wrihatnolo, Manajemen Pemberdayaan: Sebuah Pengantar dan Panduan Untuk Pemberdayaan masyarakat. Jakarta: Elex Komputindo, 2007.

[17] Abu Huraira, Pengorganisasian dan Pengembangan Masyarakat, Model dan Strategi Pembangunan Yang Bebasis Kerakyatan. Bandung: Humaniora Utama Press.

[18] A. Theresia, Pembangunan Berbasis Masyarakat. Bandung: alfabeta, 2014.

[19] A. Fahrudin, Pemberdayaan, partisipasi dan Penguatan Kapasitas Masyarakat. Bandung: Humaniora Utama Press, 2012.

[20] A. Sardjono, Hak Kekayaan Intelektual dan Pengetahuan Tradisional. Bandung: Alumni, 2006. 